\title{
The Effect of Jamblang (Syzygium Cumini (L) Skeels) Leaves Ethanolic Extract on the Adhesion of Streptococcus Mutans to Hydroxyapatite
}

\author{
Suzanna Sungkar \\ Department of Pediatric Dentistry \\ Faculty of Dentistry, Syiah Kuala University \\ Banda Aceh, Indonesia \\ Al Supartinah \\ Department of Pediatric Dentistry \\ Faculty of Dentistry, Universitas Gadjah Mada \\ Yogyakarta, Indonesia
}

\author{
Dewi Agustina \\ Department of Pediatric Dentistry \\ Faculty of Dentistry, Universitas Gadjah Mada \\ Yogyakarta, Indonesia \\ Tetiana Haniastuti \\ Department of Oral Biology \\ Faculty of Dentistry, Universitas Gadjah Mada \\ Yogyakarta, Indonesia
}

\begin{abstract}
Streptococcus mutans plays an important role in the pathogenesis of caries. This bacterium has virulence properties involve in the formation of biofilm on tooth surface. Surface protein antigen peptide (SpaP) is one of the virulence properties of $S$. mutans that play role in adhesion of $S$. mutans to the tooth structure (hydroxyapatite). Due to its antibacterial effect, Jamblang leaves may be used as an agent to reduce the adhesion $S$. mutans to the tooth surface. This study proposed to examined effects of Jamblang leaves ethanolic extract on the adhesion of $S$. mutans to hydroxyapatite (HA). Streptococcus mutans was obtained by isolating the bacteria from carious lesion of pediatric patient. Identification of $\mathrm{S}$. mutans was done by observe the characteristic of colony, carbohidrate fermentation test and biochemical test. Adhesion test was done by soaking blocks of $\mathrm{HA}$ in the mucine. The $\mathrm{HA}$ was immersed in bacterial culture that has been mixed with extract concentration of $15 \%, 20 \%$, and $22.5 \%$. Bacterial adhesion to the HA was vortexed for 60 seconds, spread on Muller Hinton Agar, and incubated for 48 hours. Colonies of $\mathrm{S}$. mutans were counted. Aquadest was used as a negative control. Kruskall-Wallis test showed significant differences $(\mathbf{p}<0.05)$ among the groups, indicating that Jamblang leaves ethanolic extract decreased the adhesion of $S$. mutans to HA. The higher concentrations of the extract, the less number of $S$. mutans colonies adhered to HA. In conclusion, Jamblang leaves ethanolic extract reduces adhesion of $S$. mutans to $H A$.
\end{abstract}

Keywords-extract Jamblang's leaves, streptococcus mutans, adhesion

\section{INTRODUCTION}

Caries was still being a dental problem in children. Data showed prevalence of caries in children was high [1]. Risk of suffering caries for preschool children (4-6 old) are relative high [2]. One of microorganisms cause of caries is Streptococcus mutans (S. mutans) [3]. Streptococcus mutans has virulence factors that play important roles in causing caries. Glucosyltransferase (gtf) synthesis is one of virulence factors, which facilitates the formation of water-insoluble glucan. The water-insoluble glucan allows S. mutans attaches and accumulates on the tooth surface [1]. An increase of water-insoluble glucan will increase the number of colonies and attachment of $\mathrm{S}$. mutans which results in an increase in plaque formation, thus increasing the likelihood of caries [4].

Streptococcus mutans also has the ability to produce acid (acidogenic), and can live in acidic condition (aciduric) [1]. In addition, S. mutans has the ability to produce polysaccharides that function as intracellular store of carbohydrate, and can be converted into acid when no carbohydrate intake available [5]. Other virulence factors of $\mathrm{S}$. mutans are surface protein antigen peptide (SpaP), consisting of the antigen $\mathrm{B}$ $(\mathrm{AgB}), \mathrm{AgI} / \mathrm{II}$, protein I (PI) plays a role in attachment of S. mutans to tooth surface. Glucan-binding protein (gbp) plays a role in unite glucan and facilitating the attachment of S. mutans to tooth surface and biofilm accumulation [6].

Jamblang (Syzygium cumini) is a plant that is widely used for health [7]. Powder of Jamblang leaves in a traditional medicine in India was used as a cleaning agent that effectively strengthens teeth and gingiva [8]. Jamblang leaves contain many flavonoids, mainly flavonoid glycosides. Jamblang leaves also contain tannins, alkaloids, saponins, and terpenoids [9].

Flavonoids, tannins and terpenoids from Jamblang leaves can disrupt the bacterial cell membrane permeability, so the bacterial growth is interrupted. Alkaloids disrupt the bacterial cell wall and intercalation into the cell wall and / or DNA, which can cause bacterial cell death [10]. Flavonoids namely quercetin, kaempherol, ellagic acid and myricetin have effect of inhibiting the enzyme activity of gtf, as well as 
tannin [6]. Therefore the content of Jamblang leaves might be used as an anticaries agent. The purpose of this study was to determine the effect of concentrations of extract Jamblang leaves to the ability of S. mutans to attach to the teeth surface. The artificial of teeth surface in this research was hydroxyapatite.

\section{MATERIALS AND METHODS}

The samples were $\mathrm{S}$. mutans isolated from deciduous molar teeth caries taken from students Kindergarten As-Surrur, Prujakan, Sleman, Yogyakarta. Streptococcus mutans isolation was done by taking specimens from deciduous molar teeth caries lesions using a sterile excavator, then placed in a tube containing thioglycolate medium. The bacteria were then grown on selective media Trypticase soy-yeast extract with $20 \%$ sucrose bacitracin (TYS20B). Streptococcus mutans identification was done by examining morphology of the colony and cell, catalase test, biochemically differentiation.

Determination of Jamblang plant was carried out in the Laboratory of Plant Taxonomy, Faculty of Biology, Universitas Gadjah Mada. The extract obtained by maceration technique using $70 \%$ ethanol. The active compounds of Jamblang leaves ethanolic extract was analyzed using Thin Layer Chromatography (TLC) and Liquid Chromatograph-Mass Spectrography (LC-MS).

The effect of ethanolic extract's concentrations of Jamblang leaves against bacterial adhesion on hydroxyapatite was examined by soaking 12 blocks of hydroxyapatite (HA) sterile size $0.5 \times 0.5 \mathrm{~mm}$ and $0.3 \mathrm{~mm}$ thick, in sterile mucine for 1 hour at room temperature. After HA coated mucine washed three times with sterile Phosphate-buffered saline (PBS), the blocks were immersed in solution of bacterial suspension $\left(1 \times 10^{6}\right.$ $\mathrm{CFU} / \mathrm{ml}$ ) and $22.5 \%, 20 \%$, and $15 \%$ extract concentrations, subsequently incubated for $90 \mathrm{~min}$ at $37^{\circ} \mathrm{C}$. After washing with PBS, S. mutans attached to HA were dispersed using a vortex, spread on MullerHinton agar (MHA) media and incubated for 48 hours at $37^{\circ} \mathrm{C}$. The number of $\mathrm{S}$. mutans colonies on the plate was counted.

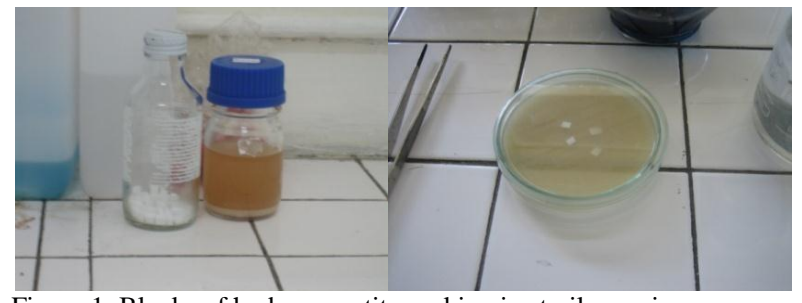

Figure 1. Blocks of hydroxyapatite soaking in sterile mucine.

\section{RESULTS}

Analysis of the active compound content of ethanolic extract of Jamblang leaves using TLC and LC-MS showed that it contains active compounds namely flavonoid (quercetin, myericetin, 3-0-a-Lrhamnocyl myricetin, taxifolin), tanin, and terpenoid (eugenyl acetate and tricosanoyl lupeol). The results of the isolation and identification of $\mathrm{S}$. mutans showed that there were three samples out of fifteen samples that have criteria as S. mutans. The Streptococcus mutans colony size was $1-2 \mathrm{~mm}$, not clear, mucoid, transparent or shiny.

The results of testing the effect of concentration of ethanolic extract of Jamblang leaves against adherence of S. mutans to the hydroxyapatite blocks showed that the extract has the ability to decrease the number of colonies of S. mutans attached to hydroxyapatite (Table I).

TABLE I. MEAN AND STANDARD DEVIATION NUMBER OF STREPTOCOCCUS MUTANS (CFU/ml) ATTACHED TO HYDROXYAPATITE IN VARIOUS CONCENTRATIONS OF ETANOLIK EXTRACT OF JAMBLANG LEAVES

\begin{tabular}{|c|c|}
\hline Group & $\overline{\mathrm{X}} \pm$ SD \\
\hline Concentration extract 22,5\% & $0.00 \pm 0.00$ \\
\hline Concentration extract 20\% & $49.33 \pm 13.35$ \\
\hline Concentration extract 15\% & $125.33 \pm 16.42$ \\
\hline Negative Control & $293.33 \pm 16.76$ \\
\hline
\end{tabular}

Normality test using Kolmogorof-Smirnov showed that the data normally distributed tested, $\mathrm{p}>0.05$ (Table II).

TABLE II. THE RESULTS OF NORMALITY TEST THE NUMBER OF S. MUTANS ATTACHED TO HIDROXYAPATITE IN VARIOUS CONCENTRATION EXTRACT ETANOLIK LEAVES JAMBLANG

\begin{tabular}{|c|c|c|c|}
\hline \multirow{2}{*}{ Group of treatment } & \multicolumn{3}{|c|}{ Kolmogorof- Smirnov } \\
\cline { 2 - 4 } & Statistic & df & Sig. \\
\hline Concentration extract $20 \%$ & 0.188 & 15 & 0.162 \\
\hline Concentration extract $15 \%$ & 0.161 & 15 & 0.200 \\
\hline Negative Control & 0.187 & 15 & 0.169 \\
\hline
\end{tabular}

Test of homogeneity shows the significance 0.000 $(\mathrm{p}<0.05)$. This means the data was tested not homogeneous, and Parametric test could not be used. Test used is Kruskal-Wallis. Summary of KruskalWallis test can be seen in Table III.

Results of Kruskal-Wallis test shows Chi Square value of 56.323 with $\mathrm{p}=0.000(\mathrm{p}<0.05)$, which means that Jamblang leaves ethanolic extract influential on the number of S. mutans attached to hydroxyapatite (Table III). Mann-Whitney test shows the difference in the number S. mutans between each group.

TABLE III. A SUMMARY OF TEST KRUSKAL-WALL IS THE NUMBER OF S. MUTANS ATTACHED TO HIDROXYAPATITE IN VARIOUS CONCENTRATION EXTRACT ETANOLIK LEAVES JAMBLANG

\begin{tabular}{|l|c|c|c|}
\hline \multicolumn{1}{|c|}{ Group } & $\begin{array}{c}\text { Rank the } \\
\text { Average }\end{array}$ & $\begin{array}{c}\text { Chi- } \\
\text { Squar } \\
\text { e }\end{array}$ & $\begin{array}{c}\text { Significance } \\
\text { (p) }\end{array}$ \\
\hline $\begin{array}{l}\text { Concentration extract } \\
22.5 \%\end{array}$ & 53 & & \\
\cline { 1 - 2 } $\begin{array}{l}\text { Concentration extract } \\
20 \%\end{array}$ & 38 & \multirow{2}{*}{56.323} & \multirow{2}{*}{0.000} \\
\cline { 1 - 2 } $\begin{array}{l}\text { Concentration extract } \\
15 \%\end{array}$ & 23 & & \\
\cline { 1 - 2 } Negative Control & 8 & & \\
\hline
\end{tabular}


Test results Mann-Whitney shows a differences significant $(p<0.05)$ of the number of $S$. mutans attached to hydroxyapatite between all groups being tested. This indicates that extracts ethanolic leaves Jamblang concentration $15 \%, 20 \%, 22.5 \%$, and control negative have a different on the number of colonies S. mutans attached to hydroxyapatite. The higher the concentration of the extract in this study, the lesser number of colonies of $\mathrm{S}$. mutans attached to hydroxyapatite. No colonies of S. mutans attached to hydroxyapatite blocks after exposed to $22.5 \%$ Jamblang leaves extract (Table IV).

TABLE IV. SUMMARY OF MANN-WHITNEY TEST RESULTS OF THE NUMBER OF S. MUTANS ATTACHED TO HIDROXYAPATITE IN VARIOUS CONCENTRATION EXTRACT ETANOLIK LEAVES JAMBLANG

\begin{tabular}{|c|c|c|c|c|}
\hline No. & \multicolumn{2}{|c|}{ Groups } & $\mathrm{Z}$ & Significance \\
\hline \multirow[t]{3}{*}{1.} & \multirow{3}{*}{$\begin{array}{l}\text { Extract } \\
22,5 \%\end{array}$} & Extract $20 \%$ & $-5,006$ & $0,000^{*}$ \\
\hline & & Extract $15 \%$ & $-4,999$ & $0,000^{*}$ \\
\hline & & Negative control & $-5,005$ & $0,000 *$ \\
\hline \multirow[t]{2}{*}{2.} & \multirow[t]{2}{*}{ Extract $20 \%$} & Extract $15 \%$ & -4.691 & $0,000 *$ \\
\hline & & Negative control & $-4,697$ & $0,000 *$ \\
\hline 3. & Extract $15 \%$ & Negative control & -4.690 & $0,000 *$ \\
\hline
\end{tabular}

The result of this study showed a decrease in the number of S. mutans inherent to hydroxyapatite in line with the increase in ethanolic concentration extract of Jamblang leaves (Table 1). As known that adhesion is important to colonization of microorganisms pathologic. Adhesion of S. mutans to the surface of the tooth is the stage important in the formation of biofilm and led to the development of caries $[11,12,13]$.

Some compound derived from plant material inhibit adhesion of bacteria on the surface of hard (glass or hydroxyapatite) and/ or bacteria aggregation. A compound polifenol in extract ethanolic leaves Jamblang can have an effect to inhibit the number of S. mutans attached to hydroxyapatite, including a compound polifenol with heavy molecules high, namely tannin [14]. Tannin can modify major surface protein of S. mutans namely antigens I/ II, that bridging an adhesions of S. mutans to HA surface [15]. Disorder on the surface proteins of $\mathrm{S}$. mutans can be lowered cell surface hydrophobicity of S. mutans and disturbing adhesion of S. mutans to the HA surface $[5,15]$.

Cell surface hydrophobicity of S. mutans is one important factor in mechanism adhesion S. mutans to the surface of the tooth. Loss of cell surface hydrophobicity of $\mathrm{S}$. mutans causes $\mathrm{S}$. mutans can not be attached to the hydroxyapatite. Cell surface hydrophobicity of S. mutans related to surface protein of S. mutans. Polyphenol polymers from plant material can react with surface proteins of $\mathrm{S}$. mutans, causing changes the cell surface hydrophobicity of S. mutans, decline in cellular aggregation and the number of $\mathrm{S}$. mutans attached to hydroxyapatite [11]. The content of eugenyl acetate and polyphenol, namely quercetin, mirisetin, taxifolin, and tannin in Jamblang leaves extract, may play a role in decreasing the number of $\mathrm{S}$. mutans attached to HA $[13,15,18]$. The higher concentration extract ethanolic leaves Jamblang, the higher the content of polifenol and eugenyl acetate, so the effect to a decrease in the number of $\mathrm{S}$. mutans attached to HA block was bigger $[13,15]$.

The adhesion of S. mutans to the tooth surface is an important step in the formation of dental plaque $[11,15]$. The first stage of $\mathrm{S}$. mutans adhesion to the tooth surface involves the interaction between the saliva, the bacterial surface, and the tooth surface. This initial adhesion is a physicochemical interaction of attraction and rejection that includes the power of Van der Waals, electrostatic and hydrophobic interactions. The bonds formed at these early attachments have a low affinity. Furthermore S. mutans form a higher bond of affinity, by utilizing specific surface molecules $[5,16,17]$.

Bacteria have components that function in adhesions called adhesin, while the component that work in the attachment that is on the host is called a receptor. The surface of bacteria can express some adhesin, while the host surface can contain some receptors [16]. Adhesin on the surface of bacterial cells is a protein present on the cell surface. Bacteria also express receptors for adhesion to other types of microbial cells used for the adhesion of cells (coaggregation). Therefore, the molecular interactions of a certain bacterium attached to different surface receptors (enamel, buccal mucosa, etc.) were different also. As a result, in a matrix biofilm can be found a lot of bacteria. Some of the bacteria that play a role in adhesion and are present in the dental biofilm include Streptococcus sp. Especially the Streptococcus mitis (S. sanguine, S. oralis, S. mitis), Actinomyces spp, S. mutans, Neisseria spp, and Haemophillus spp. Studies have shown that some types of Jamblang leaves extracts have bacteriostatic activity against Streptococcus sp., S. oralis, S. mutans, S. viridans, and Neisseria. These bacteria can form microcolony in dental biofilm, and play a role in the development of caries, so the bacteriostatic effect of the Jamblang leaves extract on these bacteria also affects to the decrease in the amount of S. mutans attached to the hydroxyapatite.

The decrease in the number of S. mutans colonies attached to the hydroxyapatite block in this study may also be due to the antibacterial effect of the extract. The content of polyphenols (quercetin, mirisetin, taxifolin, tannin) and terpenoids (eugenyl acetate and tricosanoyl lupeol) in ethanolic extract of Jamblang leaves can decrease the number of $\mathrm{S}$. mutans colonies that grow, thus affecting the number of $\mathrm{S}$. mutans colonies attached to hydroxyapatite $[18,19]$. The higher the concentration of the extract, the higher the active ingredient and the greater the effect on the decrease in the number of S. mutans attached to the hydroxyapatite block.

This study used block hydroxyapatite as a model of the tooth, while mucine was used to replace saliva in the oral cavity. Hydroxyapatite is the largest component of tooth enamel. Hydroxyapatite was used as model teeth to describe an adhesion of bacteria and the formation of biofilm that requires glycoproteins saliva 
$[18,19]$. The glycoproteins saliva allow for interaction with the surface of bacteria, so bacteria can cling stronger to hydroxyapatite [20]. Mucine used in this study to replace glycoproteins salivary.

Polyphenolic compounds namely tannins, quercetin, mirisetin, taxifolin in the ethanolic extract of Jamblang leaves can inhibit $\mathrm{S}$. mutans colonies attached to hydroxyapatite [18,21]. These compounds modify the surface proteins of S. mutans antigen I / II, which mediates the attachment of $\mathrm{S}$. mutans to HA surface. Disorders of surface proteins of S. mutans can reduce cell surface hydrophobicity of S. mutans and therefore interfere adhesion of $\mathrm{S}$. mutans to the surface of HA [14].

Decrease in the number of $S$. mutans colonies attached to the hydroxyapatite blocks in this study, may also be caused by antibacterial effects of extracts. The content of quercetin, myricetin, taxifolin, tannin, and eugenyl acetate and tricosanoyl lupeol in ethanolic extract of Jamblang leaves can kill S. mutans, thus affecting the number of $\mathrm{S}$. mutans colonies attached to hydroxyapatite [18,23].

As a conclusion, Jamblang leaves ethanolic extract have affect to one of virulence factors of Streptococcus mutans isolated from caries of preschool children. Jamblang leaves ethanolic extract $22.5 \%$ reduce the number of Streptococcus mutans attached to hydroxyapatite better than Jamblang leaves extract $20 \%$ and $15 \%$.

\section{ACKNOWLEDGEMENTS}

We would like to thank for supporting from Ministry of Research Technology and Higher Education, Research and Community Service (LPPM) Syiah Kuala University, in Research Doctoral Dissertation. Grant number 496/UN11/S/LKBOPT/2014

\section{REFERENCES}

[1] F. Ramos-Gomez, Y.O. Crystal, M.N. Ng, N. Tinanoff, D. John, J.D. Featherstone, "Caries risk assessment, prevention, and management in pediatric dental care," Gen. Dent., pp. 505-517, November 2010.

[2] S. Twetman, M. Fontana, "Patient caries risk assessment," Monogr. Oral Sci., vol. 21, pp. 91-101, 2009.

[3] S. Dhinahar, T. Lakshmi, "Role of botanicals as antimicrobial agents in management of dental infections-A review. Int. J. Pharm. Biol. Sci., vol. 2(4), pp. B690-704, 2011.

[4] R.G. Quivey, Caries. In: R.J. Lamont, R.A. Burne, M.S. Lantz, D.J. Leblanc, eds. Oral microbiology and immunology. Washington: ASM Press, 2006, pp. 233-252.

[5] R.J. Lamont, H.S. Jenkinson, Oral microbiology at a glance. Singapore: Willey-Blackwell, 2010, pp. 30-39, 41.

[6] G.F. Ferrazzano, I. Amato, A. Ingenito, A. Zarrelly, G. Pinto, A. Pollio, "Plant polyphenols and their anti-cariogenic properties: A review," J. Mol., vol.16, pp. 1486-1507, 2011.

[7] I.A. Hakimah, 81 macam buah berkhasiat istimewa. Yogyakarta: Syura Media Utama, 2010, pp. 84-86.

[8] A. Kumar, R. Ilavarasan, T. Jayachandran, M. Decaraman, P. Aravindhan, "Phytochemicals investigation on a tropical plant, syzygium cumini from Kattuppalayam, Erode District, Tamil Nadu, South India, Pakistan,” J. Nutr., vol. 8(1), pp. 83-85, 2009.

[9] A. Jain, S. Sharma, M. Goyal, S. Dubey, S. Jain, J. Sahu, et al., Anti-inflammatory activity of syzygium cumini leaves," Int. J. Phytomed., vol. 2, pp. 124-126, 2010
[10] N.C.C. Silva, A. Fernandes-Junior, "Biological properties of medicinal plants: A review of their antimicrobial activity," J. Venom Anim Toxins Incl. Trop. Dis., vol. 16(3), pp. 402-413, 2010.

[11] M. Matsumoto, T. Minami, H. Sasaki, S. Hamada, "Inhibitory effects of oolong tea extract on caries-inducing properties of mutans streptococci," Caries Res., vol. 33, pp. 441-445, 1999.

[12] G.F. Brooks, K.C. Carroll, J.S. Butel, S.A. Morse, T.A. Mietzner, Jawetz, Melnick, and Adelberg's medical microbiology, $25^{\text {nd }}$ ed., New York: McGraw-Hill, 2010, pp. $13-$ 24, 58, 60, 65-73, 149, 153, 161-162, 195-197, 203, 346-347.

[13] O. Hong-Keun, S.J. Park, H.D. Moon, S.H. Jun, C. Na-Young, Y. Yong-Ouk, "Tribulus terrestris inhibits caries-inducing properties of streptococcus mutans," J. Med. Plants. Res., vol. 5(25), pp. 6061-6066, 2011.

[14] E.A. Palombo, "Traditional medicinal plant extracts and natural products with activity against oral bacteria: Potential application in the prevention and treatment of oral diseases," Evid. Based Complementary Altern. Med., Article ID 680354, 2011.

[15] A. Yano, S. Kikuchi, T. Takahashi, K. Kohama, Y. Yoshida, "Inhibitory effects of the phenolic fraction from the pomace of vitis coignetiae on biofilm formation by streptococcus mutans," Arch. Oral Biol., XXX, AOB, vol. 2739, pp. 9, 2012.

[16] P.D. Marsh, M.V. Martin, Oral microbiology, $4^{\text {th }}$ ed. Oxford: Wright, 2000, pp. 20-22, 82-83, 89,93-99.

[17] A.H. Nobbs, R.J. Lamont, H.F. Jenkinson, "Streptococcus adherence and colonization," Microbiol. Mol. Biol. Rev., vol. 73(3), pp.407-450, 2009.

[18] X. Jing-Shu, Y. Li, X. Cao, Y. Cui, "The effect of eugenol on the cariogenic properties of streptococcus mutans and dental caries development in rats," Exp. Ther. Med., vol. 5, pp. 16671670, 2013.

[19] J.G. Jeon, M.I. Klein, J. Xiao, S. Gregoire, P.L. Rosalen, H. Koo, "Influences of naturally occurring agents in combination with fluoride on gene expression and structural organization of streptococcus mutans in biofilms," BMC Microbiol., vol. 9, pp. 228, 2009.

[20] J. Limsong, E. Benjavongkulchai, J. Kuvatanasuchati, "Inhibitory effect of some herbal extracts on adherence of streptococcus mutans," J. Ethnopharmacol., vol. 92, pp. 281289, 2004.

[21] S.D Forssten, M. Björklund, A.C. Ouwehand, "Streptococcus mutans, caries and simulation models," Nutrients, vol. 2(3), pp. 290-298, 2010

[22] H. Kuspradini, T. Mitsunaga, H. Ohashi, "Antimicrobial activity against streptococcus sobrinus and glucosyltransferase inhibitory activity of taxifolin and some flavanonol rhamnosides from kempas (Koompassia malaccensis) extracts," J. Wood Sci., vol. 55, pp. 308-313, 2009 